\title{
12. PHYSICAL PROPERTIES AND CONSOLIDATION OF THE CALCAREOUS SEDIMENTS OF BROKEN AND NINETYEAST RIDGES ${ }^{1}$
}

\author{
Elliott Taylor ${ }^{2}$
}

\begin{abstract}
Calcareous sediments cored at Broken and Ninetyeast ridges in the eastern Indian Ocean reveal the transitions from calcareous ooze to chalk and from chalk to limestone. Based on downhole porosity trends and laboratory mechanical consolidation tests, the compaction and lithification of these sedimentary sections occur at stratigraphically shallower depths than comparable marine calcareous sections. An exception to this case is the section at the northern Ninetyeast Ridge site. There, terrigenous silts and clays in the carbonate section appear to be normally consolidated. An analysis of porosity vs. depth trends of sediments from Sites 752 and 757 indicates an estimated 120 to $170 \mathrm{~m}$ of sediment were eroded during the middle Eocene uplift of this Broken Ridge.

Compositional changes in the calcareous sections alter their compaction trends: inclusion of biogenic opal and/or ash results in higher porosity and lower velocity relative to the carbonate-rich horizons. The changes are observed in laboratory and log measurements and, in places, are significant enough to produce impedance contrasts giving rise to acoustic reflectors.
\end{abstract}

\section{INTRODUCTION}

The physical properties of marine sediments are sensitive indicators of the changes in lithology, compaction history, and diagenesis. Changes in physical properties are, in turn, responsible for reflectors observed in seismic records. The sediment sections cored along the crest of Broken and Ninetyeast Ridges during Ocean Drilling Program (ODP) Leg 121 are composed primarily of pelagic carbonates. Within these sections, lithologic variations are found in occurrences of ash, differing grain-size distributions, biogenic siliceous intervals, and terrigenous sediments. These changes are reflected in variations of downhole trends in physical properties, in modified compaction behavior of the same sections, and in seismic records. Correlation of these trends and aspects of compaction with lithologic changes can lead to a better understanding of the diagenesis of these sediment columns and their geologic history.

ODP Sites 752-755 were cored along a nearly north-south transect across the crest of Broken Ridge (Peirce, Weissel, et al., 1989) (Fig. 1). The sediment section there consists of a pelagic calcareous sediment drape in unconformable contact with an underlying, northward-dipping and truncated sequence. The upper pelagic section is a nearly stark-white nannofossil with foraminifer ooze ranging in age from late Eocene to Holocene (Fig. 2). Coring at these four sites was designed to sample different stratigraphic sections of the dipping sediments. The resultant stratigraphic recovery is a section of ash-rich to calcareous sediments ranging in age from Turonian-Coniacian to early Eocene.

Three ODP sites were drilled along the crest of Ninetyeast Ridge (Peirce, Weissel, et al., 1989). Site 756 was drilled at the southerly end of this feature where a 139 -m-thick section of Pleistocene to Oligocene nannofossil ooze with foraminifers was recovered. Coring at Site 757 recovered a 212 -m-thick section of nannofossil ooze with foraminifers to chalk (Fig. 3). Ash content increases downhole in the basal section of these sediments. Site 758 was drilled at the northern end of Ninetyeast Ridge. The calcareous sediments recovered there consist of about $370 \mathrm{~m}$ of

\footnotetext{
${ }^{1}$ Weissel, J., Peirce, J., Taylor, E., Alt, J., et al., 1991. Proc. ODP, Sci. Results, 121: College Station, TX (Ocean Drilling Program).

${ }^{2}$ Woodward-Clyde Consultants, 900 Fourth Avenue, Seattle, WA 98164 , U.S.A.
}

Campanian to Holocene sediments with cherts and porcellanites in the Campanian to lower Miocene section. Terrigenous material derived from the Ganges-Brahmaputra drainage system is found in the sediment section, in increasing amounts, from the middle Miocene upward (Fig. 3). Fine-scale changes in terrigenous sediment input and their distinct physical properties are discussed in Farrell and Janecek (this volume).

\section{METHODS}

Sediment index properties (porosity, water content, bulk density) were obtained from shipboard measurements of discrete samples using gravimetric techniques and a pycnometer (Peirce, Weissel, et al., 1989). Bulk densities and porosities of sediments from above the unconformity at Broken Ridge, and from non-lithified sections at the Ninetyeast Ridge sites, were then corrected to in-situ values assuming sediment rebound as defined by Hamilton (1976) for calcareous sediments. In addition to the shipboard measurements, 12 whole-round samples were obtained for shorebased consolidation testing. The whole-rounds were X-radiographed to examine them for any obvious disturbance negating geotechnical testing. Several samples exhibited highly disturbed structures or cracks and were not included for testing. Consolidation tests were performed on 6.35 -cm-diameter samples trimmed to $2.54 \mathrm{~cm}$ in height. Water contents were obtained from trimmings of these samples and were compared against shipboard measurements to make sure no desiccation had occurred. Al samples were backpressured, as described by Lowe et al. (1964), to assure complete saturation. Samples were incrementally loaded until the virgin curve was established following standard geotechnical practice as described in Lambe (1951) and Bowles (1978).

\section{RESULTS}

Two approaches were taken to study the compaction history of the calcareous sections on the two ridges and effects of lithologic controls on the physical properties of sediments. First, downhole trends of these properties, as obtained from laboratory and logging measurements, describe the relative consolidation of these carbonate sediments with a superimposed signal resulting from lithologic variability. The effect of different lithologies and cementation can then be evaluated in terms of its role in modifying the compaction process. The second approach is to compare the mechanical consolidation behavior of samples tested under labo- 


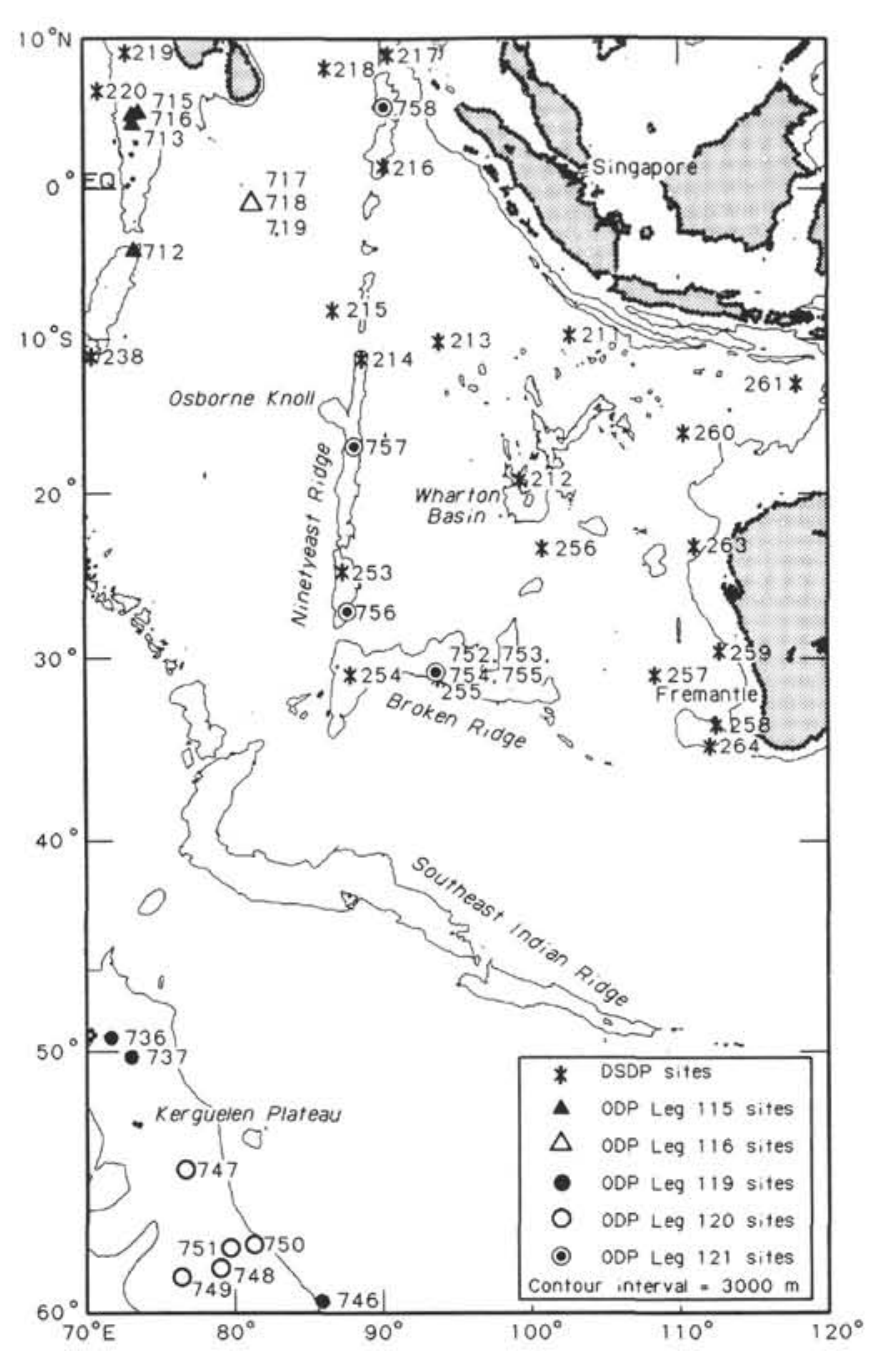

Figure 1. Location of Leg 121 sites on Broken Ridge and Ninetyeast Ridge and other ODP and DSDP sites in the eastern Indian Ocean.

ratory conditions to the observed in-situ physical changes resulting from increasing burial loads.

\section{Downhole Trends of Index Properties}

A number of downhole trends have been described for marine sediments of various compositions. Hamilton (1976) described bulk density and porosity relationships with depth for calcareous, siliceous, and terrigenous sediments. The calcareous sediments of his study are of the central Pacific Ocean sampled by Deep Sea Drilling Project (DSDP) Legs 7, 16, and 17 and of the easternmost Indian Ocean (DSDP Leg 27). Relationships for calcareous sediments have also been described by Carlson et al. (1986), Mahmood (1990), and Wilkens and Handyside (1985). Mahmood (1990) describes porosity vs. depth functions for deep sea sediments from over 110 DSDP and ODP sites. Mahmood categorized the stratigraphic units from these sites according to the predominant lithology. His study of calcareous sediments is derived from a collective data set of these sediments from the Atlantic, Pacific, and Indian oceans. Rack and Julson (in press) described relationships of index properties vs. percent calcium carbonate for samples from Site 751 on the Kerguelen Plateau. For comparison purposes, the Hamilton (1976) and Mahmood (1990) relationships for calcareous sediments are used in this study as indicators of relative trends in sediment consolidation.

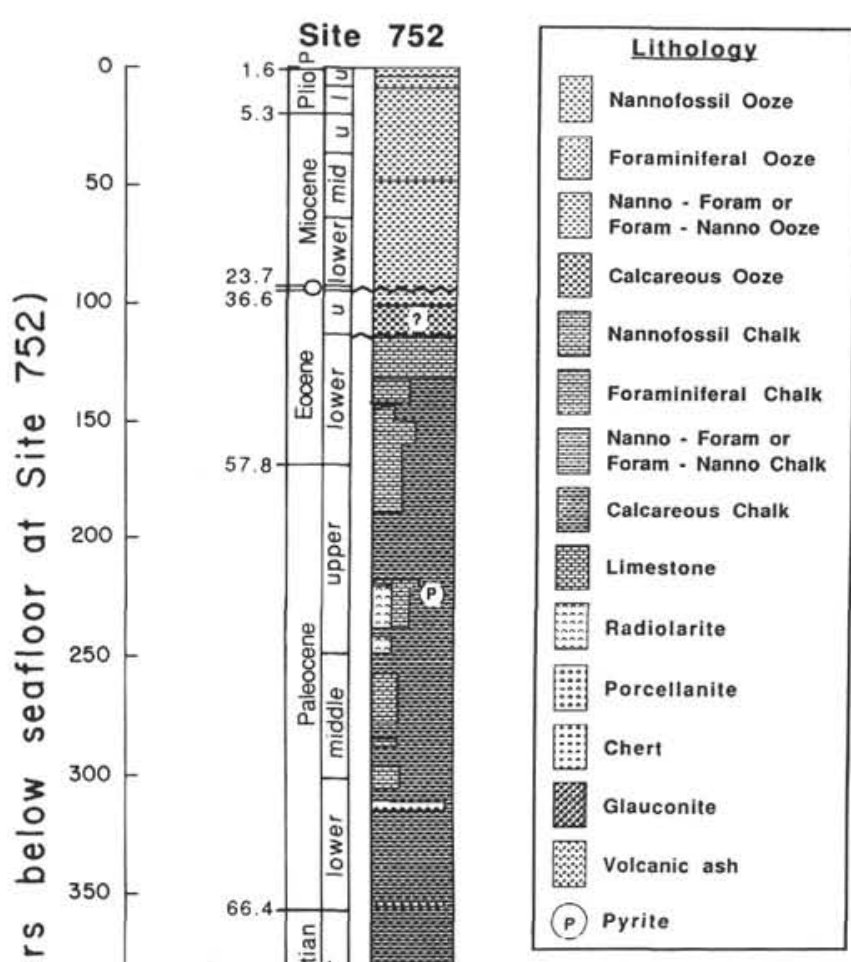

\section{Site 754}

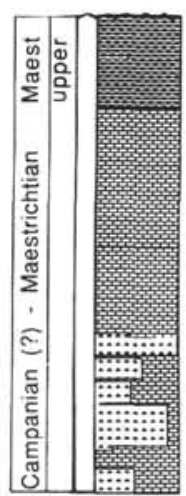

Figure 2. Lithologic summary columns of Broken Ridge Sites 752 and 754 (modified from Peirce, Weissel, et al., 1989).

The uppermost sediments at the Broken Ridge sites consist of loose, unconsolidated ooze with nearly constant density, porosity, and velocity values despite increasing burial. The bulk density of the cap sequence ranges from 1.52 to $1.75 \mathrm{~g} / \mathrm{cm}^{3}$ and velocity is nearly constant at $1500 \mathrm{~m} / \mathrm{s}$. The mean porosity of the section, corrected for compaction, is $66 \%$, which is lower than that described by Hamilton (1976) (see Fig. 4). Mahmood (1990) shows that typical surface porosities are between $70 \%$ and $75 \%$ for nannofossil and foraminifer-nannofossil oozes, respectively. His results indicate that porosities at $200 \mathrm{~m}$ are about $54 \%$ for both calcareous compositions. The average porosity of sediments between 190 and $200 \mathrm{mbsf}$ at Site 752 is $46 \%$. The porosities at Broken Ridge clearly reflect a more compacted state relative to other pelagic calcareous oozes. Furthermore, the Broken Ridge sediments exhibit a faster rate of compaction relative to the Hamilton function as the difference between these two trends increases with depth (Fig. 4). These differences reveal the relative overcompaction of sediments at Broken Ridge which, to a large 

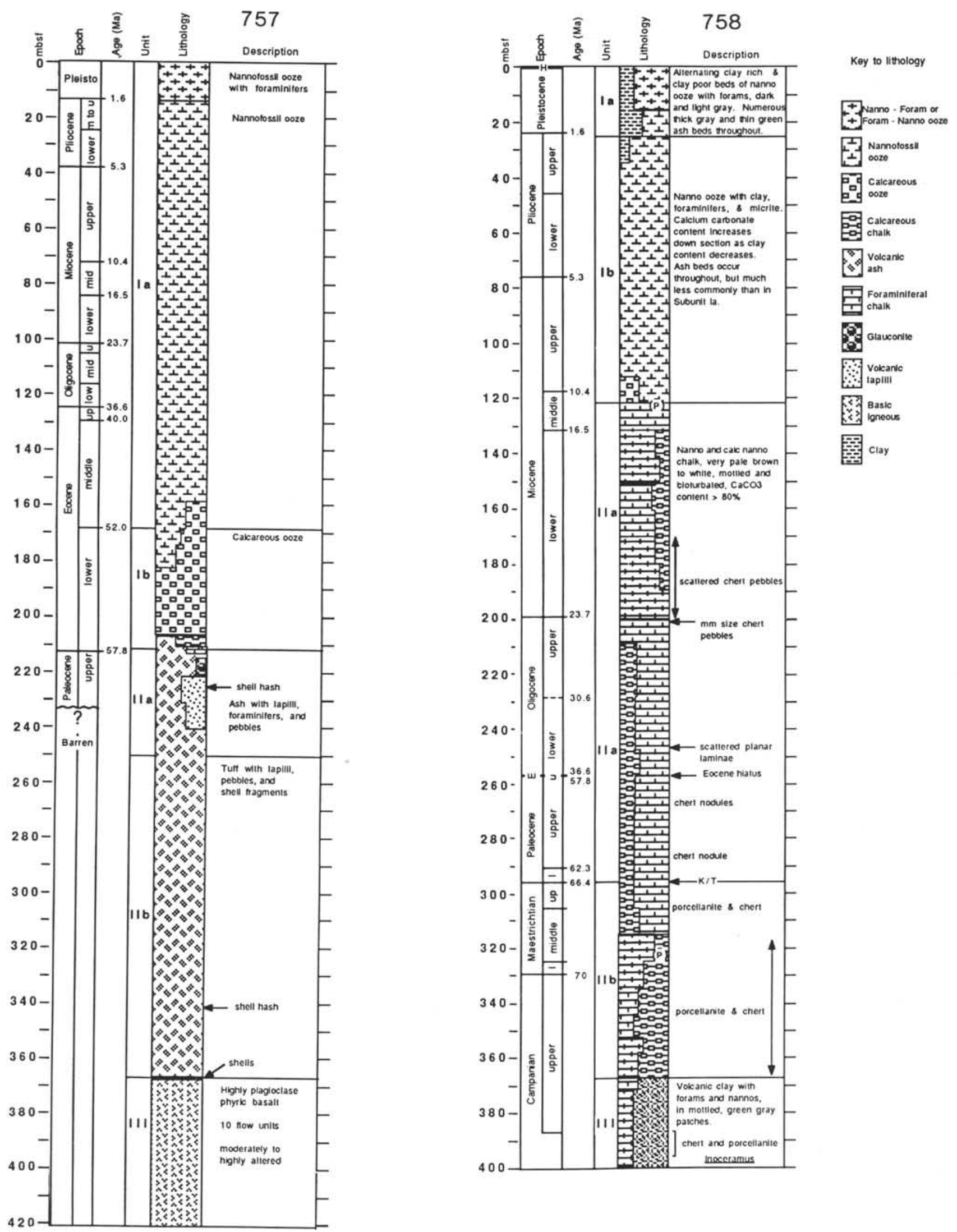

Figure 3. Lithologic summary columns of Ninetyeast Ridge Sites 757 and 758 (modified from Peirce, Weissel, et al., 1989). 


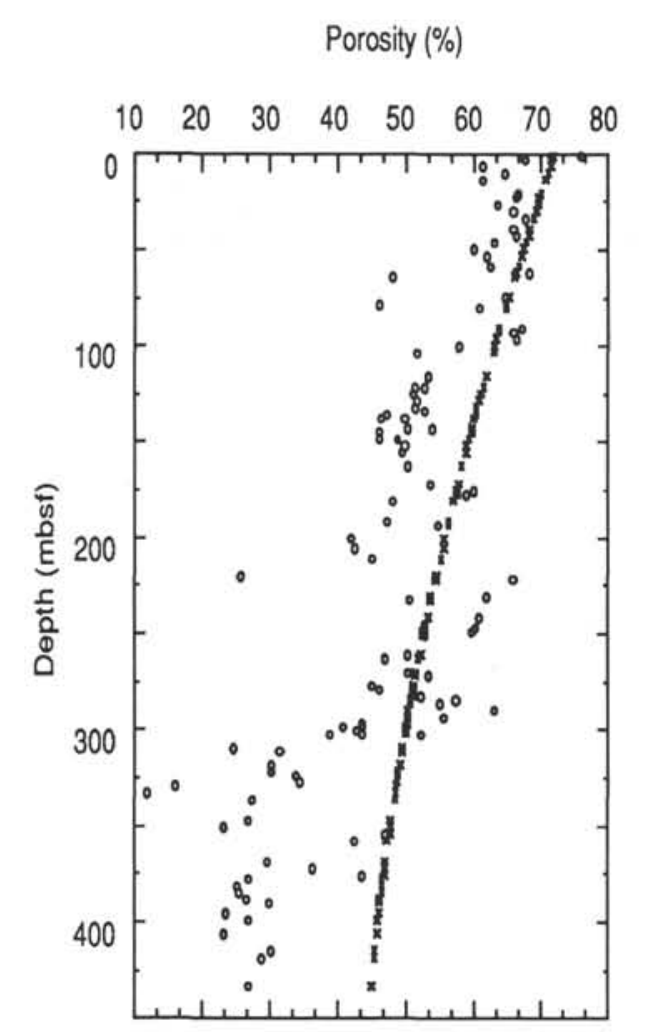

Porosity difference

Calcium carbonate (\%)
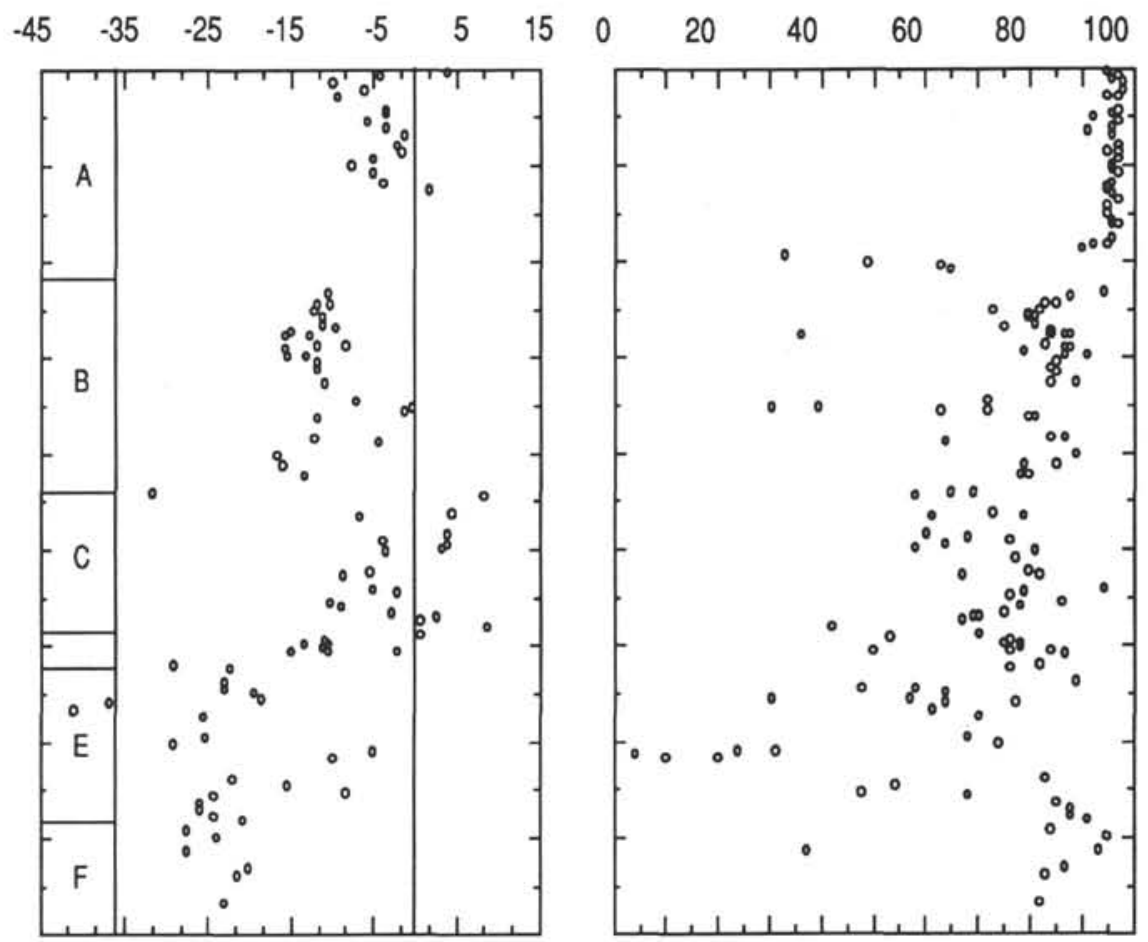

Figure 4. Porosity vs. depth for Site 752 sediments relative to the Hamilton (1976) curve for calcareous sediments (left). The difference between measured porosities (circle), corrected for rebound, and predicted porosities ( $\mathrm{x}$ ) diverges with depth (center). The divergence between these two trends does not appear to be related to a systematic change in the percentage of carbonate in these sediments (right).

extent, is a result of the removed overburden above the truncated, dipping sequence. Porosity in the lithologically similar section from Site 757 on Ninetyeast Ridge ranges from a near mud-line high of $70 \%$ to $48 \%$ at $165 \mathrm{mbsf}$ (Fig. 5). The porosity-depth trend at this site is closer to that defined by Hamilton (1979) and Mahmood (1990) near the surface but, as at Sites 752 and 754, clearly diverges with increasing depth. Unlike the Broken Ridge section, however, Site 757 has no evidence of major erosion of previously deposited sediments. Carbonate contents in all of these oozes are greater than $90 \%$, indicating a fairly homogenous composition. Some minor variations in the physical properties of the capping sequence at Broken Ridge arise from intervals of slightly coarser grain size. These intervals are interpreted as winnowed sediments (see House et al., this volume) and are characterized by small decreases in bulk density and higher porosity.

In defining the context of overall downhole trends present in the ooze-chalk-limestone transition, it is helpful to consider the combined stratigraphic sections cored at both Sites 752 and 754 . The physical aspect of the combined sections, defined through laboratory and logging measurements, can be subdivided into Units A-F (Fig. 6). Unit A, the calcareous ooze cap at Broken Ridge, is not included in this figure. Three distinct intervals mark the progressive diagenesis within the calcareous section below the unconformity (Units B, E, and F). An opal-rich interval (Unit C) disrupts the developing trend of downhole consolidation within the calcareous sequence. A short transitional section (Unit D) separates the opal-rich sediments from the calcareous section below.

The first major downhole contrast in physical properties occurs across the angular unconformity (100 mbsf in Fig. 6). The calcareous sediments below the unconformity are indurated and form chalks (Unit B). The original transition from ooze to chalk may have been much more subtle; however, erosional truncation of previous strata during the middle Eocene uplift of Broken Ridge removed the overburden that consolidated the underlying section. Bulk densities of the chalks forming Unit B range from 1.67 to $2.05 \mathrm{~g} / \mathrm{cm}^{3}$, with velocities averaging $2100 \mathrm{~m} / \mathrm{s}$. The slight variations in density and velocity within the chalks arise from minor lithologic components such as ash or chert. For comparison, the base of the calcareous section at Site 757 shows the onset of the ooze to chalk transition at about 165 mbsf. This change is indeed more subtle than that observed in the Broken Ridge sections. The change at Site 757 appears as a downhole shift to faster porosity reduction with greater depth, approximated as a porosity difference of $11 \%$ per $100 \mathrm{~m}$.

The first downhole occurrence of biogenic silica (opal-A) in the calcareous section is at 220 mbsf at Site 752 (Littke et al., this volume). The open, porous framework of diatoms and radiolarians within the carbonates gives rise to the higher mean porosity $(54 \%)$, lower mean density $\left(2.60 \mathrm{~g} / \mathrm{cm}^{3}\right)$, and lower mean velocity $(1900 \mathrm{~m} / \mathrm{s})$ within Unit C. The presence of even small amounts of opal in marine sediments is often reflected in these types of changes (Rack and Julson, in press; Pittenger et al., 1989). This zone of higher porosity is clear in both Figures 4 and 6 . The approximately 60 -m-thick interval does show a downhole consolidating trend, the base of which marks the top of the transitional Unit D at 290 mbsf (Fig. 6).

Opal persists below 290 mbsf at Site 752, though at that depth the transformation from opal-A to opal-CT has taken place. The bulk density and velocity response of the carbonate section to this transformation differs. Velocity below $310 \mathrm{mbsf}$ (Unit E) is a continuation of the general velocity-depth profile developed 
Porosity (\%)

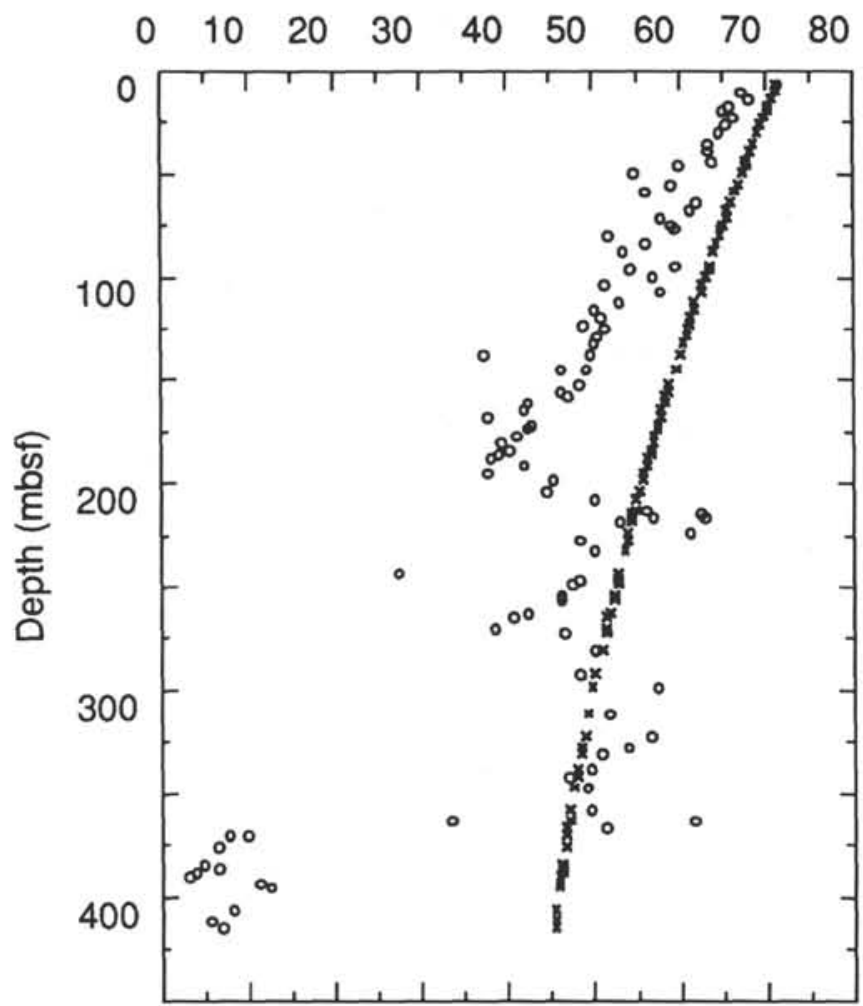

Figure 5. Porosity vs. depth for Site 757 sediments shows a divergence of measured (circle) and predicted (x) porosities similar to that of Site 752 . Semilithification of the calcareous sediments, forming chalk, occurs from 165 to $190 \mathrm{mbsf}$. Below this latter depth the sediments are tuffaceous.

above the opal-A-rich interval in Unit B. However, the contrast of bulk density and porosity between the chalk section above 220 mbsf and the interval below 300 mbsf clearly illustrates that a diagenetic reaction has taken place in the lower section. The mean bulk density and porosity of the Unit E chalks are $1.81 \mathrm{~g} / \mathrm{cm}^{3}$ and $32 \%$, respectively. The formation of lepispheres within the calcareous framework of this section may be responsible for the pronounced gradient in physical properties (Littke et al., this volume). Chalks appear to have undergone a degree of chemical cementation, creating the sharp contrast in physical properties and giving rise to a seismic reflector at about $300 \mathrm{mbsf}$ (Peirce, Weissel, et al., 1989). Opal-CT is present in the Maestrichtian sediments from Site 754, bearing similar physical properties to Site 752 .

The opal-CT-to-quartz transition occurs at the top of Unit F, about 380 mbsf at Site 752 and 320 mbsf at Site 754. No apparent bulk density or porosity change is associated with this transformation. However, the velocity profile shows an increase of about $500 \mathrm{~m} / \mathrm{s}$ relative to the general velocity-depth profile developed in Units B and E. Seismic records from this area contain a reflector that was correlated with the porcellanite-to-chert and chalk-tolimestone transition at 380 mbsf (Peirce, Weissel, et al., 1989). Dolomite and chert stringers below $525 \mathrm{mbsf}$ give rise to high velocities and bulk densities in the lowermost-sampled sediments from this stratigraphic section.

Ash within the calcareous sediments clearly modifies the response to increasing overburden that is seen in physical properties. Within the unconsolidated (ooze and chalk) sediments, ash results in higher porosity, lower bulk density, and lower velocity.

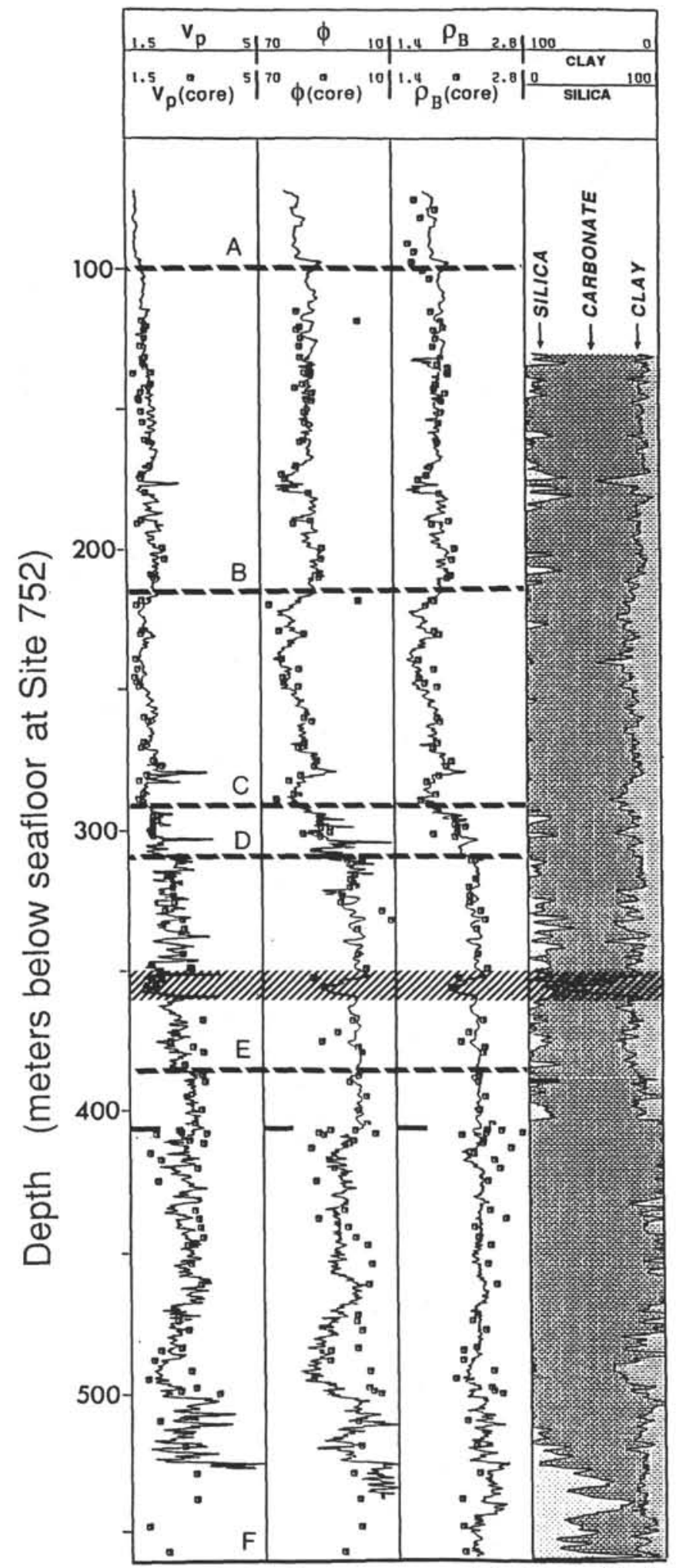

Figure 6. Laboratory (points) and log measurements of physical properties for the combined stratigraphic sections of Sites 752 and 754 reveal the effects of the removed sediment cover corresponding to the angular unconformity at the sites. Presence of biogenic opal between 220 and 290 mbsf results in higher porosities and lower velocity. Note that this silica phase is not detected in the geochemical log. Ash-rich intervals punctuate the continued downhole trend in physical properties, indicated by small increases in porosity and lower velocity and bulk density (e.g., the zone of the Cretaceous/Tertiary boundary highlighted by cross-hatching). 
For example, the presence of an ash-rich interval at the Cretaceous/Tertiary boundary (345-365 mbsf in Fig. 6) in the Broken Ridge section is obvious in both laboratory and logging physical properties. Similar response is evident in the interval from 470 to 495 mbsf (Fig. 6) and in the sediments underlying the calcareous section at Site 757 (Fig. 5).

\section{Consolidation Tests}

Six specimens, obtained from between 10 and $118 \mathrm{mbsf}$, were consolidated in laboratory tests to observe the mechanical change in porosity $(n)$, or void ratio $(e)$, as a function of applied vertical load $[e=1 /(n+1)$ where $n$ is fraction porosity]. An important consideration in interpreting these tests is the disturbance the sample has undergone during coring, retrieval, and handling. Typically, hydraulic piston coring may induce disturbance to loose, unconsolidated calcareous sediments (Walton et al., 1983). A measure of this disturbance may be indicated from the shape of void ratio vs. applied stress curves, or $e-\log p$ curves. This disturbance becomes critical when estimating in-situ vertical stresses under which sediments appear to have been loaded, which is referred to as pre-consolidation stress $\left(p^{\prime}{ }_{c}\right)$. In the present study, however, these data are not used for interpretation. Instead, the change of void space as a function of applied stress is used to compare mechanical compaction of laboratory specimens to that observed in the field. Typically, void ratio decreases as a linear function of the log of effective stress under basinal-type loading. This type of loading occurs where the principal stress is vertical and simply results from the stress of overlying sediments. A useful quantitative measure of this change is the compression index, $c_{c}$, which is defined as:

$$
c_{c}=-\Delta e / \Delta \log p^{\prime}
$$

where $p^{\prime}$ is the effective applied stress. These tests illustrate the changes that the sediment samples are likely to undergo under simple vertical loading. Hence, the collective group of Leg 121 samples is used to indicate the general response of the sediments to mechanical compaction, with variations resulting from compositional differences among samples.

Typical $e-\log p$ plots indicate the load response of samples from Sites 752, 757, and 758 (Fig. 7). These curves generally progress from nearly horizontal (little void reduction) at low loads, through a zone of maximum curvature (intermediate loads), to a straight segment or virgin curve (higher loads). Section $121-758 \mathrm{~A}-5 \mathrm{H}-6,140-150 \mathrm{~cm}$, is a good example of a typical e-log p curve. The latter portion of the curve exemplifies sediment consolidation under new loads whereas the maximum curvature represents transition from the reloading to virgin compression. This break is near the maximum effective stress with which the sediment had equilibrated prior to testing (if undisturbed, this is the preconsolidation stress, or effective in-situ vertical stress, in cases of normal loading). The degree of curvature from reloading to virgin curve is an indication of sediment disturbance; a better defined break between these portions of the curve represents less disturbance.

The compression index, $c_{c}$, is defined from the virgin curve. For the clean, calcareous sediments of Sites 752 and 757 , this coefficient ranges from 0.11 to 0.27 , with an average of 0.17 . The value of $c_{c}$ is slightly greater for the foraminifer nannofossil oozes found in surface sediment of Section 121-757B-2H-4, 140-150 $\mathrm{cm}$. This difference is attributed to the mechanical breakage of the foraminifer tests (Demars, 1982). The $c_{c}$ for Site 758 samples, however, is much higher and averages 1.12. This faster rate of compaction is typical of sediments with a terrigenous component, as noted by Bryant et al. (1981) and the Geotechnical Consortium (1984). These same sediments also have a higher mud-line poros- ity of about $77 \%$ which closely corresponds to silty calcareous clays (Bryant et al., 1981; Mahmood, 1990).

\section{DISCUSSION}

Through comparison of changes in physical properties at the study sites to those general trends described for similar compositions, it is evident that the Leg 121 sediments behave differently, with the exception of Site 758 samples. The calcareous sediments examined in this study generally have lower overall porosities and faster downhole compaction trends than those defined by Hamilton (1976) and Mahmood (1990). The difference in relative compaction rate suggests another process is active in these sections from Leg 121. At Broken Ridge, the compaction differences must be considered in light of the overburden that was eroded when the ridge was uplifted above the wave base during the middle Eocene. The ridge later subsided and gained its pelagic cap, but left a more compacted section nearer the mud-line. However, even the pelagic cap exhibits lower overall porosities relative to the comparable studies of Hamilton (1976) and Mahmood (1990).

The differences between the porosities of the Broken Ridge calcareous sediments and those of Hamilton (1976) can be used to estimate the amount of overburden eroded at the unconformity. The average porosity difference of the pelagic cap relative to Hamilton's function is $-4.2 \%$ porosity. The average difference in the chalk section of Site 752 from 100 to 212 mbsf is $-11.2 \%$ porosity. The vertical offset required to yield porosities in the chalk section that are near $4 \%$ porosity lower than the Hamilton function is about $170 \mathrm{~m}$. Another approach to estimate the eroded overburden is to use the porosity vs. depth function of Site 757 calcareous sediments, assuming these underwent a similar compaction history to those of Broken Ridge but without the erosional episode. This function can be approximated by a linear regression given as:

$$
n=69.4-0.158(\mathrm{mbsf}) \text { and } r=0.92 \text {. }
$$

Using this relationship, the porosities of the chalk section of Unit B correspond to burial depths of about $120 \mathrm{~m}$ deeper than their present depth. From these two estimates, the overburden eroded at the unconformity at Site 752 is between 120 and $170 \mathrm{~m}$.

Laboratory consolidation data for the Site 758 silty calcareous sediments and downhole trends of physical properties closely follow those defined elsewhere for similar sediment composition. The compression index of the calcareous sections at Sites 752 and 757 (ca. 0.17 ) can be expressed as a porosity difference within the same 100 - to $200-\mathrm{m}$ interval. A $c_{c}$ of 0.17 corresponds to a porosity change of $4 \% / 100 \mathrm{~m}$, equivalent to that described by Mahmood (1990). This similarity suggests the mechanical consolidation of the test specimens is representative of most unconsolidated calcareous sections. However, the mechanically induced rate of change in void space reduction does not match that observed from the field trends. Because the downhole data reflect a faster compaction rate, chemical diagenesis and subsequent lithification is interpreted to play a key role early in the diagenesis and consolidation of the calcareous sections on these ridges. A relative index of the role of chemical diagenesis in these calcareous section may be interpreted from the increasing difference between the measured porosity and the Hamilton (1976) trend (Fig. 4). From the viewpoint of geotechnical testing, this diagenetic process is apparent in the field consolidation curve. The field $e-\log p$ curve is a plot of measured void ratios vs. calculated in-situ effective overburden stress using bulk density, depth, and assuming hydrostatic conditions. Figure 8 shows the progressive change in compaction rate with applied load for Site 757. For typical viscoelastic response in sediments, the compression index is a straight line. The field $e-\log p$ curve for Site 757 

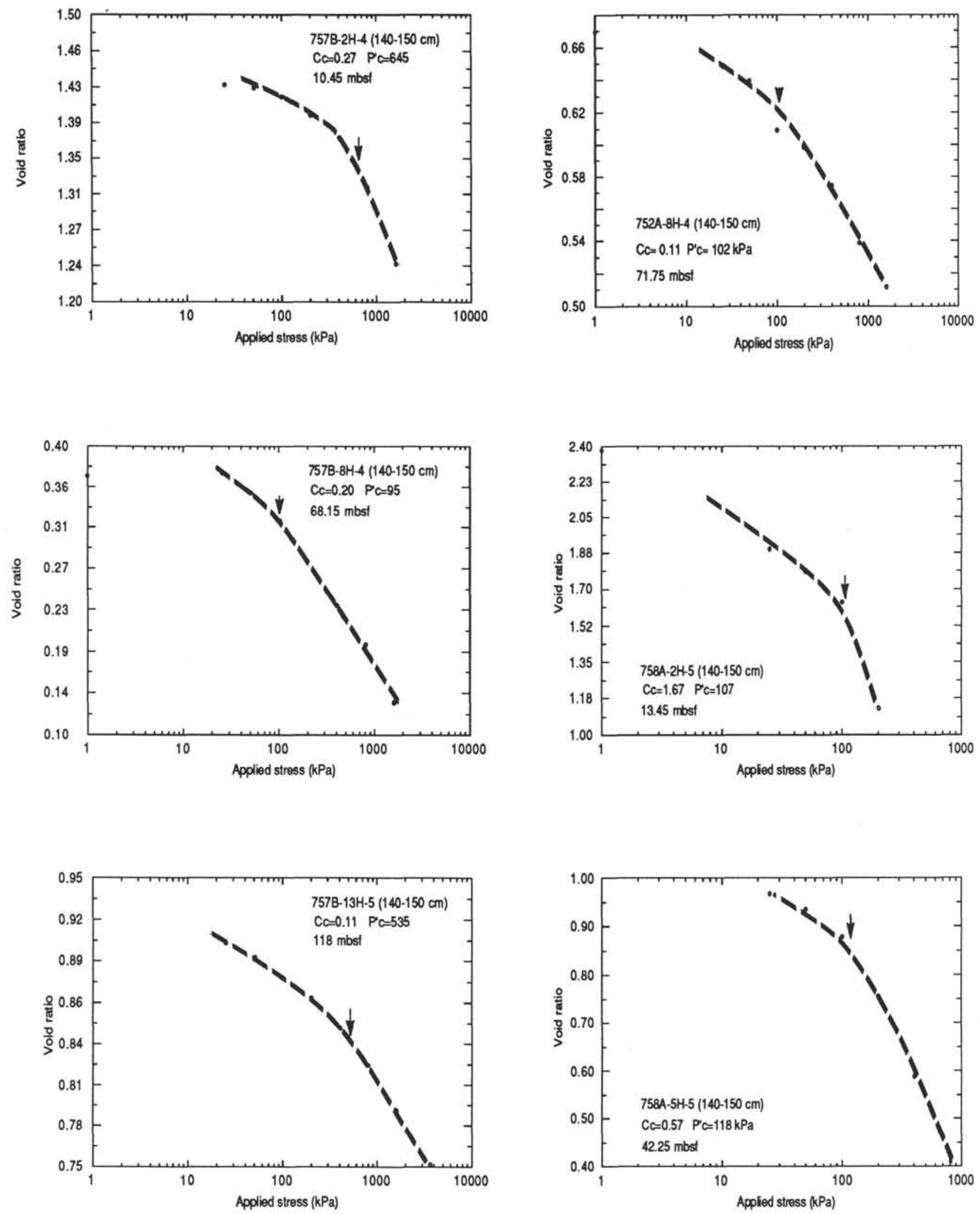

Figure 7. Void ratio vs. applied stress curves, $e-\log p$, of the consolidation tests performed on Leg 121 samples. The higher compressibility of calcareous sediments with a terrigenous component relative to purely calcareous sediments is evident from comparing Site 758 samples to those of Sites 752 and 757 . 


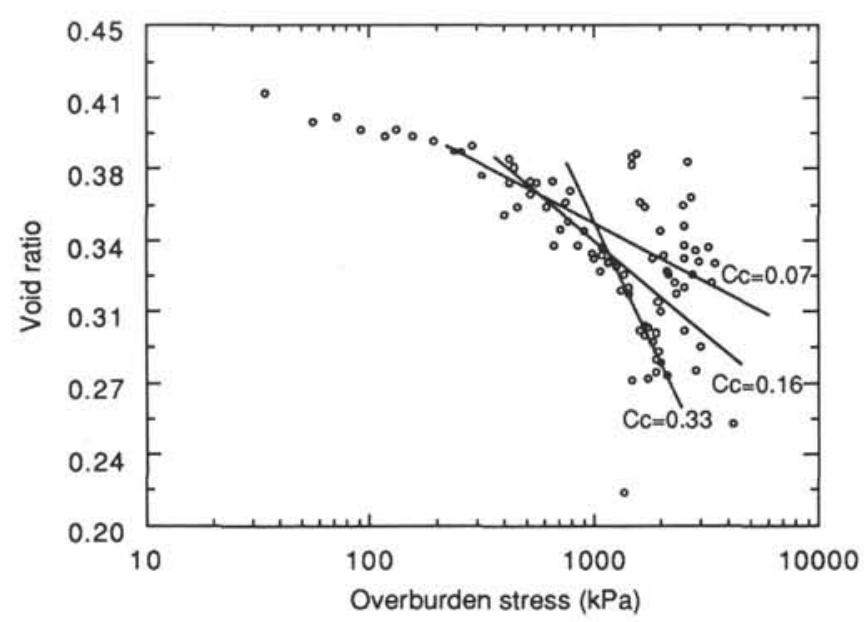

Figure 8. A field consolidation curve for Site 757 sediments illustrates the change in compressibility as stress (depth) increases. The compression index of nannofossil oozes ranges from 0.11 to 0.16 , while the chalk interval has an index of 0.33 .

shows that a regular change in the compression index characterizes that sequence. In the same figure, the ash-rich interval illustrates a very distinct behavior, retaining high void ratios under load with no evident trend. The interval described as chalk by Leg 121 scientists occurs just above the ash-rich zone (lower stress) and exhibits a compression index of 0.33 . This increase of the compression index is another measure of the lithification process occurring in that sediment section which is not related to mechanical consolidation.

\section{SUMMARY}

The calcareous sediments at Sites 752, 754, and 757 exhibit the change from unconsolidated ooze, through chalk, to limestone. These same sediments, however, are initially more compacted than equivalent calcareous sections and appear to make the transition through the lithification process faster than comparative examples. This behavior may be attributed to chemical diagenesis that is present higher in the lithologic column. The Broken Ridge sites have a thin pelagic cover overlying a truncated, dipping sequence that is clearly more consolidated. The erosion of between 120 to $170 \mathrm{~m}$ of uplifted material at Broken Ridge placed more compacted sediments nearer the mud-line, and hence results in an apparent lithification process that is shallow in the stratigraphic section. Site 757 , however, has a normal stratigraphic succession with no apparent erosional history, yet it also indicates an accelerated lithification relative to other pelagic calcareous sections. Physical properties which developed in downhole trends and geotechnical testing may serve as good indicators of the relative importance of mechanical consolidation and lithification through chemical diagenesis.

\section{ACKNOWLEDGMENTS}

The author is grateful to the shellbacks of Leg 121, as they provided a constant source of hard work and play, and always with a sense of humor. The yeoperson was particularly instrumental in helping the author maintain his priorities throughout the shipboard and shore-based work. This project was supported by a grant from the JOIDES-USSAC program administered through the Texas A\&M Research Foundation. The manuscript benefitted from the reviews of N. Driscoll and G. Karner.

\section{REFERENCES}

Bowles, J. E., 1978. Engineering Properties of Soils and Their Measurements: New York (McGraw-Hill).

Bryant, W. B., Bennett, R. H., and Katherman, C. E., 1981. Shear strength, consolidation, porosity, and permeability of oceanic sediments. In Emiliani, C. (Ed.), The Sea (Vol. 7): New York (Wiley), 1555-1616.

Carlson, R. L., Gangi, A. F., and Snow, K. R., 1986. Empirical reflection travel time versus depth and velocity versus depth functions for the deep-sea sediment column. J. Geophys. Res., 91:8249-8266.

Demars, K. R., 1982. Unique engineering properties and compression behavior of deep-sea calcareous sediments. In Demars, K. R., and Chaney, R. C. (Eds.), Geotechnical Properties, Behavior, and Performance of Calcareous Soils: Philadelphia (ASTM), 92-112.

Geotechnical Consortium, 1984. Geotechnical properties of sediments from Walvis Ridge, Deep Sea Drilling Project, Leg 75, Hole 532A. In Hay, W. W., Sibuet, J.-C., et al., Init. Repts. DSDP, 75: Washington (U.S. Govt. Printing Office), 1109-1127.

Hamilton, E. L., 1976. Variations in density and porosity with depth in deep-sea sediments. J. Sediment. Petrol., 46:280-300.

Lambe, T. W., 1951. Soil Testing for Engineers: New York (Wiley).

Lowe, J., Zaccheo, P. F., and Feldman, H. S., 1964. Consolidation testing with back pressure. J. Geotech. Eng. Div., Am. Soc. Civ. Eng., 90: 69-86.

Mahmood, K., 1990. Porosity gradients in marine sediments [M.S. thesis]. Texas A\&M Univ., College Station, TX.

Peirce, J., Weissel, J., et al., 1989. Proc. ODP, Init. Repts., 121: College Station, TX (Ocean Drilling Program).

Pittenger, A., Taylor, E., and Bryant, W. R., 1989. The influence of biogenic silica on the geotechnical stratigraphy of the Vøring Plateau, Norwegian Sea. In Eldholm, O., Thiede, J., Taylor, E., et al., Proc. ODP, Sci. Results, 104: College Station, TX (Ocean Drilling Program), 923-940.

Rack, F., and Julson, A. P., in press. Sediment microfabric and physical properties record of the late Neogene polar front development, Site 751. In Wise, S. W., Jr., Schlich, R., et al., Proc. ODP, Sci. Results, 120: College Station, TX (Ocean Drilling Program).

Walton, W. H., Sangrey, D. A., and Miller, S. A., 1983. Geotechnical engineering characterization of hydraulically piston-cored deep ocean sediments. In Barker, P. F., Carlson, R. L., Johnson, D. A., et al., Init. Repts. DSDP, 72: Washington (U.S. Govt. Printing Office), 537-550.

Wilkens, R., and Handyside, T., 1985. Physical properties of equatorial Pacific sediments. In Mayer, L., Theyer, F., Thomas, E., et al., Init. Repts. DSDP, 85: Washington (U.S. Govt. Printing Office), 839-847.

Date of initial receipt: 3 August 1990

Date of acceptance: 27 November 1990

Ms 121B-161 